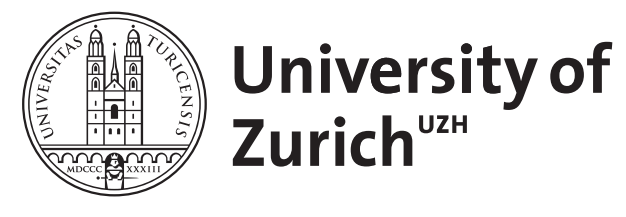

\title{
Sovereign defaults and liquidity crises
}

Brutti, Filippo

\begin{abstract}
Sovereign debt crises in emerging markets are usually associated with liquidity and banking crises. The conventional view is that the domestic financial turmoil is the consequence of foreign retaliation, although there is no clear empirical evidence on "classic" default penalties. This paper emphasizes instead a direct link between sovereign defaults and liquidity crises, building on two natural assumptions: (i) government bonds represent a source of liquidity for the domestic private sector; (ii) the government cannot discriminate between domestic and foreign creditors in the event of default. In this context, external debt emerges even in the absence of classic penalties and government default is counter cyclical, triggers a liquidity crunch, and amplifies output volatility. In addition, a financial reform that involves a substitution of government bonds with privately-sourced liquidity instruments could backfire by restricting government's access to foreign credit.
\end{abstract}

DOI: https://doi.org/10.1016/j.jinteco.2011.02.001

Posted at the Zurich Open Repository and Archive, University of Zurich

ZORA URL: https://doi.org/10.5167/uzh-57965

Journal Article

Accepted Version

Originally published at:

Brutti, Filippo (2011). Sovereign defaults and liquidity crises. Journal of International Economics, $84(1): 65-72$.

DOI: https://doi.org/10.1016/j.jinteco.2011.02.001 


\title{
Sovereign Defaults and Liquidity Crises*
}

\author{
Filippo Brutti \\ University of Zurich and Study Center Gerzensee
}

First Draft: October 2008

This Draft: January 2011

\begin{abstract}
Sovereign debt crises in emerging markets are usually associated with liquidity and banking crises. The conventional view is that the domestic financial turmoil is the consequence of foreign retaliation, although there is no clear empirical evidence on "classic" default penalties. This paper emphasizes instead a direct link between sovereign defaults and liquidity crises, building on two natural assumptions: (i) government bonds represent a source of liquidity for the domestic private sector; (ii) the government cannot discriminate between domestic and foreign creditors in the event of default. In this context, external debt emerges even in the absence of classic penalties and government default is countercyclical, triggers a liquidity crunch, and amplifies output volatility. In addition, a financial reform that involves a substitution of government bonds with privately-sourced liquidity instruments could backfire by restricting government's access to foreign credit.
\end{abstract}

Keywords: Legal institutions, liquidity, sovereign risk, financial dependence JEL Classification: F34, O16.

\footnotetext{
*This paper, previously circulated with the title "Legal Enforcement, Public Supply of Liquidity and Sovereign Risk", was the first chapter of my dissertation while at Universitat Pompeu Fabra. I am grateful to Jaume Ventura for his valuable guidance and countless suggestions, as well as Peter Benczur, Fernando Broner, Paula Bustos, Antonio Ciccone, Davide Debortoli, José Antonio Dorich, Nathan Foley-Fisher, Miklos Koren, Gino Gancia, Nicola Gennaioli, Dirk Niepelt, Silvana Tenreyro, Joachim Voth, Vivian Yue, Fabrizio Zilibotti, the editor Jonathan Eaton and an anonymous referee for helpful comments. I am particularly indebted with Alberto Martin for discussing with me the idea of the paper since the very beginning. I also benefited from comments at the Bank of Hungary, Bank of Italy, EPFL Lausanne, Federal Reserve Board, Study Center Gerzensee, Universitat Pompeu Fabra, University of Warwick, University of Zurich and at the "Micro and Macroeconomic Effects of Financial Globalization" NBER conference. Financial support from the European Research Council (ERC Advanced Grant IPCDP-229883) is gratefully acknowledged. Any error is my own.
} 


\section{Introduction}

Sovereign debt crises in emerging markets are usually associated with liquidity and banking crises. Borensztein and Panizza (2008) show that sovereign default was, in fact, a good predictor of a banking crisis in many emerging countries during the period from 1980 to $2000 .{ }^{1}$ The conventional view interprets domestic turmoil as an indirect consequence of foreign retaliation, for example trade sanctions or exclusion from international financial markets. ${ }^{2}$ Yet, this interpretation is controversial. First, there is no clear-cut empirical evidence supporting the application of "classic" penalties. ${ }^{3}$ Second, in recent sovereign crises (e.g., Argentina 2001 and Russia 1998) government default had a direct "balance-sheet" effect on domestic financial institutions, which were major holders of public debt (Mishkin, 2006). In this paper, I study the direct connection between sovereign defaults and liquidity crises abstracting from external penalties.

The model builds on two natural assumptions for emerging markets. First, public debt represents a source of liquidity for the private sector. Specifically, domestic firms need to refinance their projects in the future but are not able to access spot credit markets due to limited enforcement of creditors' rights. Firms then save in government bonds, either directly or indirectly through the banking sector, to hoard a reserve of liquidity. This aspect of the model is consistent with the negative correlation observed in the data between creditors' rights protection and banks' holdings of government debt. ${ }^{4}$ Second, the government cannot discriminate between domestic and foreign bondholders in the event of default. This assumption, which hinges on both the anonymity and the increasing integration of secondary markets for government bonds, is consistent with the large haircuts suffered by domestic financial institutions during recent debt crises.

The implications of these two assumptions are clear. Sovereign default has opposing effects on the domestic economy as, on the one hand, it avoids a transfer of domestic resources to foreign creditors while, on the other, it generates a liquidity crisis that disrupts private investment and lowers domestic production. The trade-off faced by the government then explains the emergence of sovereign debt even in the absence of foreign penalties. Nevertheless, a default might occur in some states. In particular, sovereign default is countercyclical, as a drop in aggregate productivity lowers the cost of triggering a liquidity crisis, and has an amplification effect on the business cycle, as the shortage of liquidity dampens private investment and output.

\footnotetext{
${ }^{1}$ These authors apply a methodology similar to Kaminsky and Reinhart (1999) and show that the probability of a banking crisis conditional on a sovereign default in the same year or in the year before is statistically larger than the unconditional probability while this is not the case for the probability of a sovereign default conditional on a banking crisis.

${ }^{2}$ The nature of costs associated with default has been studied extensively since Eaton and Gersovitz (1981) and Bulow and Rogoff (1989). Scholars agree that debt repayment hinges on a sovereign's willingness to avoid the cost of a default given that existing legal arrangements do not provide sufficient protection of creditors' rights (due to the jurisprudential principle of "sovereign immunity"). See Grossman and Van Huyck (1988), Bulow and Rogoff (1989), Fernandez and Rosenthal (1990), Cole and Kehoe (1998), Kletzer and Wright (2000), Wright (2002), Amador (2004), Yue (2005), Aguiar and Gopinath (2006) and Arellano (2008), among others. Eaton and Fernandez (1995), Sturzenegger and Zettelmeyer (2006) and Panizza et al. (2009) survey this literature.

${ }^{3}$ See Borensztein and Panizza (2008).

${ }^{4}$ See Kumhof and Tanner (2005).
} 
Having established the link between sovereign defaults and liquidity crises, the paper discusses a novel implication of financial reforms; namely, reforms do not necessarily raise domestic welfare and, in some cases, can backfire on welfare. Consider a reform that enables domestic firms to hedge their future refinancing needs using some type of contingent contracts rather than resorting to precautionary savings in non-contingent government bonds. Conventional wisdom suggests that this reform must have a positive effect on welfare as it allows firms to reallocate efficiently liquidity across future states. However, this interpretation considers only one aspect of the reform. The reverse aspect of it is that the consequent decline in domestic holdings of public bonds makes government's default less costly and, therefore, it might restrict the government's prior access to foreign credit. In conclusion, an assessment that focuses exclusively on the efficiency gains for the private sector could overestimate the true effect of a financial reform by failing to recognize that the reform could involve a reallocation of capital from the public to the private sector, which would be particularly detrimental in countries with large returns on public infrastructures.

Two strands of the literature are brought together in this paper. First, the motivation for holding government bonds is based on the corporate finance approach to liquidity hoarding (e.g., Holmstrom and Tirole, 1998). According to these authors, whenever in the economy there is a demand for liquid assets which cannot be satisfied by the private sector due to a lack of commitment, the government can intervene by issuing government bonds, which are implicitly guaranteed by the government's ability to commit agents' income through taxation. A common counterargument, however, is that integration with a mature market, having a virtually unbounded financial capacity, could alleviate the need for government intervention in the economy; indeed, foreign bonds represent a perfect substitute for government bonds. Yet, this paper shows that this is not true in general and, therefore, the existence of a market for government bonds can enhance liquidity even in open economies. More specifically, a slight and realistic modification of Holmstrom and Tirole's framework, that is, the inclusion of sovereign risk, implies that foreign bonds are no longer perfect substitutes for government bonds. The intuition is that the government can manipulate the returns on public bonds and make them procyclical, allowing domestic bondholders to efficiently reallocate resources across states of nature.

The second strand of the literature that is closely related to this paper includes a number of recent papers that focus on the direct consequences of sovereign default on the domestic private sector (e.g., Broner and Ventura, 2011, 2008; Guembel and Sussman, 2009; Gennaioli et al., 2009). ${ }^{5}$ These papers have in common with mine the assumption that government's repayment is non-discriminatory across domestic and foreign creditors, but they emphasize different implications: the welfare and distributional effects of default, the political process governing sovereign repayment and the interaction between private and public capital flows, respectively. My paper concentrates on the emergence of a liquidity crisis in the event of default and on the disruption

\footnotetext{
${ }^{5}$ See also Sandleris (2008) and Basu (2008).
} 
of private investment.

With regard to the empirical evidence, the paper documents that sovereign debt crises are associated with domestic liquidity crises. Using sectoral data for a panel of 59 emerging countries over the period from 1980 to 2000, the evidence shows that sovereign defaults exert a differential effect across manufacturing sectors, which is both statistically and economically significant, suggesting that financially dependent industries experience sharper contractions. Furthermore, the evidence shows that the domestic liquidity crisis is not fully explained by the contraction in foreign credit to the private sector in the event of a sovereign default.

The remainder of the paper is organized as follows. Section 2 presents the model and discusses the main results. Section 3 addresses the consequences of a financial reform in this framework. Section 4 presents the empirical evidence and section 5 concludes.

\section{A model of sovereign risk and liquidity crises}

This section first characterizes a stylized economy where government debt represents a source of liquidity due to frictions in private credit markets. It then analyzes the implications of sovereign risk on private investment and aggregate output.

\subsection{Technology}

Consider a small open economy that lasts for three periods: $t=0,1,2$. There is a single homogenous good which is produced by a continuum of risky investment projects. Investment in each project $j$ costs one unit of the good in $t=0$ and returns $\theta A_{j}$ in $t=2$ where $\theta$ and $A_{j}$ denote two independent shocks realized in $t=1$. $\theta$ captures an aggregate shock, which affects all projects equally and takes values $\theta_{H}>1$ with probability $\pi_{H} \equiv \pi\left(\theta_{H}\right)$ (good state) and $\theta_{L}<1$ with probability $\pi_{L} \equiv \pi\left(\theta_{L}\right)=1-\pi_{H}$ (bad state). For simplicity, normalize the expected value of the aggregate shock to one, that is, $\pi_{H} \theta_{H}+\pi_{L} \theta_{L}=1$. $A_{j}$ captures an idiosyncratic shock, which affects each project individually and takes values $A>0$ if the project is lucky and zero if the project is unlucky. Each project has an equal probability of being lucky or unlucky. In the latter case, the project admits an additional investment with variable size, $i$, which returns $\theta \rho i$ in $t=2$. Setting $A / 2>1$ and $\theta_{L} \rho>1$, both date 0 and date 1 investments are profitable. Figure 1 describes the timing of investment projects.

\subsection{Agents and Preferences}

The economy is populated by a continuum of individuals with mass one who have zero initial endowment, consume only at date 2 and are risk neutral. There are two types of individuals: 
Figure 1: Timing of investment projects

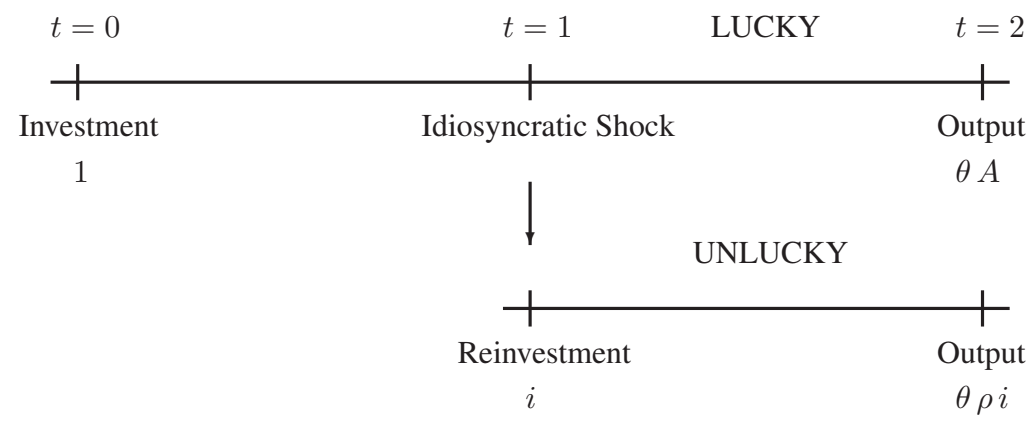

entrepreneurs (firms) and workers, both with mass one half. Entrepreneurs have access to the investment technology and each one can start a single project. Workers, on the other hand, have no access to the investment technology, but derive income $w$ at date 1 . There is also a benevolent government that maximizes the average welfare of domestic individuals. At date 0 , the government has access to a public investment project with rate of return $\phi>1$ and maximum size $\bar{g}$.

\section{$2.3 \quad$ Financial Frictions}

The economy is financially integrated with an international financial market (IFM), which is risk neutral, has deep pockets and can lend/borrow at a zero interest rate. As the economy has zero initial endowment, both the entrepreneurs and the government borrow from the IFM to finance their projects. Let's now discuss the type of financial frictions existing in this economy. First, entrepreneurs have limited access to credit due to weak enforcement of creditors' rights, which reflects the inability of courts of law to seize the entire value of a debtor's assets.

Assumption 1 Entrepreneurs can pledge only a fraction $\gamma$ of expected revenues, while workers cannot commit their future income.

It is well known that financial frictions influence financial decisions in many ways. ${ }^{6}$ Here, I focus on the demand for liquidity assuming (i) $\gamma A / 2>1$ and (ii) $\gamma \theta_{H} \rho<1$. These two conditions imply, respectively, that date 0 investment is profitable for the IFM, but date 1 investment

\footnotetext{
${ }^{6}$ Since the seminal contribution of Modigliani and Miller (1958), financial frictions and their consequences have attracted a growing literature. Hubbard (1998) and Stein (2003) provide two excellent surveys. A necessarily incomplete list of past contributions include: Bernanke and Gertler (1989) and Kiyotaki and Moore (1997) on the link between credit cycles and business cycles; Matsuyama (2004), Caballero et al. (2008) on international capital flows and global imbalances; Aghion et al. (2004), Caballero and Krishnamurthy (2001), Mendoza (2006) on emerging market crises and sudden stops.
} 
is not. Hence, unlucky entrepreneurs cannot borrow on the spot market to finance additional investment.

Firms could meet their refinancing needs by negotiating a contingent contract with the IFM, which promises a positive transfer in the case of adverse expenditure shock and a negative transfer in the alternative case. However, for the time being, I restrict this possibility.

Assumption 2 Entrepreneurs cannot enter into contingent contracts with the IFM.

Assumption 1 and 2 together imply that firms need to save for future investment, and they can do so only by purchasing non-contingent bonds. In this integrated economy, entrepreneurs can choose between a foreign bond issued by the IFM and a public bond issued by the domestic government. The government, indeed, issues a one-period bond in $t=0$ to finance the investment in the public project and repays it by collecting lump-sum taxes at date 1 . Sovereign risk arises whenever the government cannot commit to repay in the future.

Assumption 3 The government commits to repay its debt with probability $\pi_{G}$.

If $\pi_{G}=1$, there is full commitment, and the government always repays. If $\pi_{G}=0$, there is full discretion, and the government can choose whether to repay to maximize the welfare of domestic individuals. Following Broner and Ventura (2011), I consider that in the event of a default the government cannot discriminate between domestic and foreign creditors.

Assumption 4 The government cannot discriminate between domestic and foreign creditors.

Assumption 4 is consistent with the large haircuts suffered by domestic financial institutions on government bonds during recent debt crises (e.g., Russia 1998 and Argentina 2001). It also reflects the recent development of liquid secondary markets for sovereign bonds, which makes the gathering of informations on individual bondholders both unfeasible and inefficient for the government. ${ }^{7}$

\section{Equilibrium}

This section solves for the competitive equilibrium of the model under two opposite regimes: the case of full commitment by the government $\left(\pi_{G}=1\right)$ and the case of full discretion $\left(\pi_{G}=0\right)$. The

\footnotetext{
${ }^{7}$ Suppose the government could discriminate among domestic and foreign bondholders. Expecting a default on their bond holdings, foreigners would always unfold their positions before maturity by selling bonds on the secondary market to domestics, which have the incentive to buy the bond at any non-negative discount since they know the government has no incentive to default on domestic debt. This way, foreigners receive de facto their payment. Hence, if the government wants to avoid the repayment of foreigners, it must commit to default on all bond holders indiscriminately, for instance by not gathering information on secondary market transactions. By doing so, the government gains an additional degree of freedom and, as shown in the next section, can implement a contingent repayment policy that benefits domestic agents. The following quote from Reinhart et al. (2003) is enlightening: "the view that external debt is completely separable from domestically issued debt is dead wrong"
} 
comparison between the two cases makes clear why domestic agents buy government bonds rather than foreign bonds and the connection between sovereign defaults and liquidity crises.

\subsection{Equilibrium with government commitment}

At date 0 , the representative entrepreneur borrows $d$ from the IFM and saves in government and foreign bonds up to a face value $b$ and $f$ so as to maximize the expected profit

$$
\sum_{\theta} \pi(\theta)\left(\frac{y_{l}(\theta)+y_{u}(\theta)}{2}\right)-d
$$

where $y_{l}(\theta)=\theta A+(b+f-\tau)$ and $y_{u}(\theta)=\theta \rho(b+f-\tau)$ denote, respectively, the output from a lucky and an unlucky project. Notice that I have implicitly imposed that on date 1 unlucky entrepreneurs fully reinvest in the project, that is, $i=b+f-\tau$. This is without loss of generality given that the additional investment has strictly positive net returns. The budget constraint of the entrepreneur is

$$
1+b+f=d
$$

where both government and foreign bonds have unit price and the initial investment in the project equals one. Limited contract enforcement restrains date 0 borrowing by imposing

$$
d \leq \gamma \sum_{\theta} \pi(\theta)\left(\frac{y_{l}(\theta)+y_{u}(\theta)}{2}\right)
$$

Maximization of (1) subject to (2)-(3) yields a corner solution where the borrowing constraint is binding and government and foreign bonds are perfect substitutes. This follows from the fact that the expected return on each of the two bonds is higher than the cost of borrowing, that is, $\bar{\rho} \equiv(1+\rho) / 2>1$. In particular, the entrepreneur's saving in the two bonds satisfies

$$
b+f=\frac{\gamma\left(\frac{A}{2}-\bar{\rho} \tau\right)-1}{1-\gamma \bar{\rho}} .
$$

Aggregation across individuals implies that the average income of entrepreneurs is $Y_{E}(\theta)=$ $\left(y_{l}(\theta)+y_{u}(\theta)\right) / 2-d$, and the average income of workers is $Y_{W}=w-\tau$. The problem of the government then consists in choosing the public investment $g$ to maximize the expected value of social welfare

$$
\sum_{\theta} \pi(\theta) W(\theta)=\sum_{\theta} \pi(\theta)\left(\frac{1}{2} Y_{E}(\theta)+\frac{1}{2} Y_{W}+\phi g\right)
$$

subject to date 0 and date 1 budget constraints, that is, $B=g$ and $\tau=B$ respectively. Because 
the government undertakes the public investment only if the social return from it, given by the marginal product of the project minus the marginal cost of taxation, is positive, in equilibrium we get

$$
g=\left\{\begin{array}{ll}
\bar{g} & \text { if } \quad \phi \geq \frac{1}{2}\left(1+\frac{(1-\gamma) \bar{\rho}}{1-\gamma \bar{\rho}}\right) \\
0 & \text { if } \quad \phi<\frac{1}{2}\left(1+\frac{(1-\gamma) \bar{\rho}}{1-\gamma \bar{\rho}}\right)
\end{array} .\right.
$$

Finally, market clearing imposes that there is equality between supply and demand for government bonds, that is, $g=B=1 / 2 b+b^{*}$ where $b^{*}$ denotes the amount of government bonds purchased by the IFM. Henceforth, consider that public investment has positive net returns, and thus $g=\bar{g}$, and that the demand for bonds by domestic entrepreneurs is strictly lower than the supply of government bonds, that is, $\bar{g}>1 / 2(b+f)$. This restriction ensures that the government needs to borrow from abroad and makes the sovereign risk problem interesting.

\subsection{Equilibrium with sovereign risk}

Assume now that the government cannot commit to repay. In the absence of discrimination between domestic and foreign creditors, the government faces a clear trade-off at the moment of repayment. On one hand, debt repayment involves an efficient reallocation from workers to entrepreneurs, which raises aggregate investment, but, on the other hand, it requires a transfer to the IFM, which reduces the resources available for domestic consumption.

Let $e \in\{0,1\}$ denote the repayment choice of the government, where $e=1$ indicates repayment and $e=0$ indicates default. Repayment occurs only if the average income gain of entrepreneurs (LHS) compensates the average income loss of workers (RHS), or

$$
Y_{E}(\theta, e=1)-Y_{E}(\theta, e=0) \geq Y_{W}(e=0)-Y_{W}(e=1)
$$

where $Y_{E}(\theta, e)=\left(y_{l}(\theta, e)+y_{u}(\theta, e)\right) / 2-d$ denotes the average income of entrepreneurs, which depends on the policy $e$ through the face value of government bonds and taxation as shown by

$$
y_{l}(\theta, e)=\theta A+f+e(b-\tau) \quad \text { and } \quad y_{u}(\theta, e)=\theta \rho(f+e(b-\tau))
$$

while $Y_{W}(e)=w-e \tau$ denotes the average income of workers.

By substituting for $\tau=1 / 2 b+b^{*}$ using the government's budget constraint and the market clearing condition on date 1 , it is easy to see that, for a given level of the external debt $b^{*}$, the LHS of (5) increases with aggregate productivity; indeed, a higher $\theta$ raises the return from reallocating wealth from workers to entrepreneurs. Therefore, there may be situations where 
debt repayment is procyclical, that is, $e=1$ if $\theta=\theta_{H}$ and $e=0$ if $\theta=\theta_{L}$. This actually turns out to be the case in equilibrium.

On date 0 , each entrepreneur observes the holdings of government bonds of other domestic entrepreneurs and the IFM. If the entrepreneur expects the government to repay in all future states, he will be indifferent between saving in domestic and foreign bonds and his level of saving will be given by (4), as before. If instead the entrepreneur expects the government to repay only in the good state, he will choose $\{d, b, f\}$ to maximize

$$
\sum_{\theta} \pi(\theta)\left(\frac{y_{l}(\theta, e)+y_{u}(\theta, e)}{2}\right)-d
$$

subject to the budget constraint

$$
1+f+\pi_{H} b=d,
$$

where the price of government bonds is actuarial fair as agents are risk neutral, and the borrowing constraint

$$
d \leq \gamma \sum_{\theta} \pi(\theta)\left(\frac{y_{l}(\theta, e)+y_{u}(\theta, e)}{2}\right) .
$$

Maximization of (6) subject to (7)-(8) implies that domestic entrepreneurs save exclusively in domestic government bonds. Indeed, the repayment of government bonds is now contingent on the state of the economy and domestic firms save in government bonds to reallocate liquidity to the state in which the productivity of additional investment is higher. More formally, a simple rearrangement of (6) shows that by saving in government bonds domestic entrepreneurs receive an expected return $\bar{\rho}_{H} \equiv\left(1+\theta_{H} \rho\right) / 2$ which is greater than the expected return on foreign bonds, $\bar{\rho}=(1+\rho) / 2$. As long as both returns exceed the borrowing rate, constraint (8) must be binding and the following condition holds:

$$
b=\frac{\gamma\left(\frac{A}{2}-\pi_{H} \bar{\rho}_{H} \tau\right)-1}{\pi_{H}\left(1-\gamma \bar{\rho}_{H}\right)} \quad \text { and } \quad f=0 .
$$

Given the choice of entrepreneurs, the government chooses $g$ to maximize the expected value of social welfare

$$
\sum_{\theta} \pi(\theta) W(\theta, e)=\sum_{\theta} \pi(\theta)\left(\frac{1}{2} Y_{E}(\theta, e)+\frac{1}{2} Y_{W}(e)+\phi g\right)
$$

subject to date 0 and date 1 budget constraints, that is, $\pi_{H} B=g$ and $e \tau=e B$ respectively. In the absence of commitment, however, debt repayment must be incentive compatible at least when $\theta=\theta_{H}$ to induce individuals to buy government bonds, and the following constraint must 
be satisfied in equilibrium:

$$
Y_{E}\left(\theta_{H}, e=1\right)-Y_{E}\left(\theta_{H}, e=0\right) \geq Y_{W}(e=0)-Y_{W}(e=1) .
$$

Assuming that the social return on public investment is positive, ${ }^{8}$ maximization of (10) implies the incentive-compatibility constraint (11) is binding and, using the market clearing condition $B=1 / 2 b+b^{*}$, external debt is equal to

$$
b^{*}=\left(\frac{\bar{\rho}_{H}-1}{\bar{\rho}_{H}+1}\right) \frac{b}{2} .
$$

The explanation of this result is quite intuitive. At this level of foreign borrowing, the government implicitly commits to repay only in the good state of the economy, thus benefitting domestic entrepreneurs who can shift liquidity to the most productive state by saving in government bonds. Furthermore, the investment in public project and the social return on it are maximized.

\subsection{Discussion}

The previous model justifies the emergence of sovereign debt in the absence of classic penalties. It also establishes a connection between sovereign defaults and liquidity crises that disrupt private investment and amplify output volatility. Both results arise as a consequence of the fact that public debt serves as a repository of liquidity to the domestic private sector. Given that generality has been sacrificed in favor of analytical simplicity, a detailed discussion of the main aspects of the model is required.

The model extends to the case of open economies the common argument, formalized by Holmstrom and Tirole (1998), that government debt represents a source of liquidity for the economy. The justification of the original argument is that whenever there is a demand for liquid assets in the economy and the private sector cannot supply a sufficient amount of assets due to a lack of commitment, the government can intervene by issuing government bonds, which are implicitly guaranteed by the government's ability to commit agents' income through taxation. Arguably, however, when the economy is financially integrated with a large financial market, the need for government intervention is somewhat reduced; indeed, foreign bonds represent a perfect substitute for government bonds. Yet, when sovereign risk is considered, the two assets become imperfectly substitutable; indeed, government bonds allow domestic firms to reallocate efficiently wealth across states of nature. Admittedly, risk aversion, not in this model, could play a crucial role and, in fact, domestic agents would not hold domestic government bonds if they were

\footnotetext{
${ }^{8}$ As before, the social return on public investment is positive whenever the marginal product from the project exceeds the implied cost of taxation, i.e., $\phi \geq \frac{1}{2}\left(1+\frac{(1-\gamma) \bar{\rho}_{H}}{1-\gamma \bar{\rho}_{H}}\right)$. In addition, I assume that the upper bound on public investment $\bar{g}$ is sufficiently high to ensure that the incentive-compatibility constraint can be binding in equilibrium.
} 
sufficiently averse to risk. ${ }^{9}$ The nature of liquidity needs then becomes crucial. In particular, if agents save liquidity to invest in the future, they prefer portfolios that perform better when the economic outlook is good, and new investment opportunities are about to come. In such a case, government bonds constitute a better investment strategy. On the contrary, if they save to finance future consumption, they rather choose portfolios with countercyclical returns to hedge against adverse income shocks (e.g., wage cuts, unemployment). ${ }^{10}$

As a matter of fact, government bonds are commonly held by financial institutions while firms rely on banks to manage their liquidity needs (e.g. through cash deposits or credit lines). In particular, empirical evidence suggests that government bonds typically constitute a large fraction of domestic banks' assets with higher figures corresponding to developing countries and, among this group, to countries with weak creditors' rights protection (Reinhart et al., 2003; and Kumhof and Tanner, 2005). This observation, however, is not inconsistent with the model. Consider a slightly modified framework including a competitive banking sector that borrows from the IFM and lends to domestic firms. This setup, suggested by Gennaioli et al. (2009), is clearly equivalent to the previous one whenever there is no commitment problem between banks and firms (i.e., banks can monitor projects), but there is a commitment problem between banks and the IFM (i.e., banks can pledge only a fraction of their assets to foreign creditors). ${ }^{11}$ Hence, the two frameworks have no major differences in terms of main results, although the second interpretation provides a more compelling description of reality. ${ }^{12}$

In the model, government debt enhances private liquidity because it allows agents to redistribute wealth from taxpayers to entrepreneurs in the intermediate period. Alternatively, we could consider that the government could transfer wealth through taxation. This possibility, which was implicitly ruled out in the model, would make sovereign debt unsustainable; indeed, the government could default on debt to avoid the repayment of foreign bondholders and, nonetheless, transfer resources to entrepreneurs by taxing workers. This type of redistribution, however, is arguably not feasible due to either political costs or the reluctance of distressed agents to accede publicly-sponsored financing that could reveal information to the market (an example of that is the scarce success to the Fed discounted window facility during the recent US crisis). Furthermore, the assumption of non-discrimination in taxation is a common assumption in the literature (Broner and Ventura, 2011; Guembel and Sussman, 2009; Gennaioli et al., 2009).

\footnotetext{
${ }^{9}$ However, the preference for government bonds is robust to low level of risk aversion.

${ }^{10}$ In the model, the choice between domestic and foreign bonds arises from the optimizing behavior of domestic entrepreneurs. Nevertheless, it could be argued that governments often resort to financial repression to place their debt with domestic financial institutions. In this case, the consequence of a sovereign default thus far described will be at play, notwithstanding the actual willingness of domestic agents to hold government bonds.

${ }^{11}$ The equivalence between the two frameworks is evident when we consider that each bank lends to just one firm.

${ }^{12}$ In particular, the inclusion of a banking sector that holds government bonds and grants loans to firms can justify the observation of interest rate spikes in the event of default; indeed, a default on government bonds could weaken banks' balance sheets and force banks to cut back on credit to private sector in order to reduce their leverage. This credit crunch ultimately could cause tighter competition for funds by firms and, in the presence of decreasing returns, mounting interest rates.
} 
The need for public supply of liquidity hinges on the absence of a private market for contingent assets. This assumption, which is taken as a given in the model, can be easily justified considering that the idiosyncratic expenditure shock is private information, and agents cannot write contracts contingent on it. The next section relaxes this assumption and studies the implications arising from a gradual expansion of individuals' access to contingent contracts.

\section{Financial reforms}

In the late 1990's, the US federal debt paydown raised practitioners' worries that a declining volume of government bonds could restrain the ability of the private sector to hoard liquidity and spurred the development of alternative liquidity-enhancing financial instruments (Reinhart and Sack, 2000; BIS, 2000; Fleming, 2001). Twisting this argument, one could argue that the recent expansion of over-the-counter markets in emerging economies, which enhanced the ability of firms to insure against future liquidity shocks using a wide range of new instruments (IMF, 2004), will possibly reduce the domestic appetite for public bonds as a repository of liquidity and, eventually, limit government's access to foreign credit. This section discusses the welfare implications that arise from this type of financial reform.

Assumption 2 imposed that firms could not enter into contingent contracts with the IFM and could refinance their investment only by deploying previous savings in non-contingent bonds. Relaxing this assumption, suppose there are two types of domestic firms: good firms, which can trade contingent contracts, and bad firms, which cannot. ${ }^{13}$ A reform that expands derivative markets in the economy can then be mimicked by an exogenous increase in the fraction of good firms.

Assumption 5 Let $\lambda$ denote the fraction of good firms in the economy, that is, firms that can enter into a contract contingent on the expenditure shock.

As previously shown, bad firms maximize their expected profits by saving in government bonds up to

$$
b=\frac{\gamma\left(\frac{A}{2}-\pi_{H} \bar{\rho}_{H} \tau\right)-1}{\pi_{H}\left(1-\gamma \bar{\rho}_{H}\right)}
$$

\footnotetext{
${ }^{13}$ One interpretation for good and bad firms is that the former are well-regulated and transparent firms with foreseeable cash-flows from their assets while the latter are badly regulated and opaque firms holding assets with uncertain values.
} 
which is equivalent to (9), and derive expected income

$$
\begin{aligned}
\sum_{\theta} \pi(\theta) & Y_{E}^{B}(\theta, e)= \\
& =\sum_{\theta} \pi(\theta)\left(\frac{y_{l}^{B}(\theta, e)+y_{u}^{B}(\theta, e)}{2}\right)-d^{B} \\
& =\frac{A}{2}+\pi_{H}\left(\bar{\rho}_{H}-1\right) b-1-\pi_{H} \bar{\rho}_{H} \tau
\end{aligned}
$$

where I have substituted for $d^{B}=1+\pi_{H} b$, and the fact that, in equilibrium, the government repayment policy is procyclical (i.e., $e=1$ if $\theta=\theta_{H}$ and $e=0$ if $\theta=\theta_{L}$ ).

Good firms, on the other hand, can save in a foreign security that is contingent on the aggregate productivity shock, as government bonds, but also on the idiosyncratic expenditure shock. This type of securities will naturally arise in equilibrium (provided foreign markets can observe the idiosyncratic shock to firms) as it maximizes firms' profits by allowing them to shift liquidity both across aggregate and idiosyncratic states. Let $x$ denote the amount of foreign securities purchased by each good firm and let $q=\pi_{H} / 2$ be the actuarial fair price of each foreign security. Good firms maximize their expected profits by purchasing foreign securities up to

$$
x=\frac{\gamma\left(\frac{A}{2}-\pi_{H} \bar{\rho}_{H} \tau\right)-1}{\pi_{H}\left(\frac{1+\gamma}{2}-\gamma \bar{\rho}_{H}\right)}
$$

and receive expected income

$$
\begin{aligned}
\sum_{\theta} \pi(\theta) Y_{E}^{G}(\theta, e)= \\
\quad=\sum_{\theta} \pi(\theta)\left(\frac{y_{l}^{G}(\theta, e)+y_{u}^{G}(\theta, e)}{2}\right)-d^{G} \\
=\frac{A}{2}+\pi_{H}\left(\frac{\theta_{H} \rho-1}{2}\right) x-1-\pi_{H} \bar{\rho}_{H} \tau
\end{aligned}
$$

where I have substituted for $d^{G}=1+\pi_{H} / 2 x$, and $e=1$ if $\theta=\theta_{H}$ and $e=0$ if $\theta=\theta_{L}$.

Given that $x>b$ since $\gamma<1$ and $\left(\bar{\rho}_{H}-1\right)=\left(\theta_{H} \rho-1\right) / 2$, conditions (13) and (14) imply that good firms receive higher expected income than bad firms. Not surprisingly, the ability to trade contingent securities improves firms' efficiency in allocating wealth across states of nature. Thus, a reform that expands the fraction $\lambda$ of good firms within the economy increases the expected income of the private sector.

Let's now study the implications of this reform on the government's access to foreign credit. The problem of the government is to choose the investment $g$ to maximize the expected social 
welfare

$$
\sum_{\theta} \pi(\theta) W(\theta, e)=\sum_{\theta} \pi(\theta)\left(\frac{\lambda}{2} Y_{E}^{G}(\theta, e)+\frac{1-\lambda}{2} Y_{E}^{B}(\theta, e)+Y_{W}(e)+\phi g\right)
$$

subject to the budget balance conditions $g=\pi_{H}\left(\frac{1-\lambda}{2} b+b^{*}\right)$ and $\tau=\frac{1-\lambda}{2} b+b^{*}$ and the incentivecompatibility constraint

$$
\begin{aligned}
\frac{1-\lambda}{2}\left(Y_{E}^{B}(\theta, e=1)-Y_{E}^{B}(\theta, e=0)\right) \geq \frac{\lambda}{2}\left(Y_{E}^{G}(\theta, e=0)-Y_{E}^{G}(\theta, e=1)\right) & + \\
& +\left(Y_{W}(e=0)-Y_{W}(e=1)\right) .
\end{aligned}
$$

Suppose again that public investment yields a positive social return. ${ }^{14}$ As discussed before, the government will borrow up to the point in which the incentive-compatibility constraint (16) is binding to maximize public investment and, therefore,

$$
b^{*}=\left(\frac{\bar{\rho}_{H}-1}{\bar{\rho}_{H}+1}\right) \frac{(1-\lambda)}{2} b
$$

Equation (17) shows that an increase in $\lambda$ restrains the government's access to foreign credit and, therefore, the size of public investment. The welfare consequences of the reform, hence, are ambiguous; indeed, substitution of (17) into (15) implies that social welfare increases with $\lambda$ only if the marginal benefit to the private sector, $\sum_{\theta} \pi(\theta)\left(Y_{E}^{G}(\theta, e)-Y_{E}^{B}(\theta, e)\right)$ is greater than the foregone return on public investment, $\left[\pi_{H} \phi+d\left(\sum_{\theta} \pi(\theta) W(\theta, e)\right) / d \tau\right] \cdot \partial b^{*} / \partial \lambda$.

\subsection{Discussion}

The previous section delivers a simple but powerful result. The common presumption that a complete market for private claims necessarily raises welfare might not be robust to the inclusion of an interaction between private and public debt markets. In particular, the efficiency gains in the allocation of capital across private agents might overestimate the real effect of the reform, which could involve a reallocation of capital from the public to the private sector. This could be particularly detrimental in poor countries with large returns on public infrastructures. Strong policy prescriptions, however, are undoubtedly misplaced in this simple environment. For instance, a relaxation of the benevolent government assumption yields diametrically opposite implications. In such a case, welfare rises when the government borrows less and, therefore, the improvement in domestic financial markets will have a beneficial disciplining effect on public expenditure. ${ }^{15}$ Far from making normative statements, this paper suggests that financial reforms deliver novel

\footnotetext{
${ }^{14}$ This is ensured by the condition imposed in the previous section, i.e., $\phi \geq \frac{1}{2}\left(1+\frac{(1-\gamma) \bar{\rho}_{H}}{1-\gamma \bar{\rho}_{H}}\right)$.

${ }^{15} \mathrm{I}$ am grateful to an anonymous referee who suggested this interpretation.
} 
implications on the composition of capital flows.

An alternative interpretation of the model suggests that governments might oppose financial liberalization and resort to some form of financial repression to sustain domestic holdings of government debt. Mishkin (2006) reports the case of Argentina where bank reserve requirements clearly privileged government bonds by classifying them as "being the least risky of all assets that a bank could hold" and by successively raising the share of government bonds in total reserves to allow the central government to collocate additional debt. This example suggests that inefficient institutions tend to be particularly persistent for reasons that differ from the ones already discussed in the literature, which stress the role of initial conditions that are extremely costly to revert or political economy reasons to maintain the status quo.

\section{Sovereign defaults and liquidity crises: empirical evi- dence}

This section documents that sovereign debt crises are associated with liquidity crises. The empirical evidence suggests that sovereign defaults prompt sharper contractions in industries that depend on external sources of finance. The evidence also shows that the domestic liquidity crisis in the event of default cannot be fully ascribed to the decline in foreign credit, in line with the previous model.

I test the distinct impact of sovereign default across manufacturing industries using the following empirical model,

$$
g_{i, c, t}=\alpha_{i, c}+\lambda_{i, t}+\mu_{c, t}+\left(\beta_{F} F D_{i}+\beta_{X} X_{i}\right) \cdot D_{c, t}+\epsilon_{i, c, t},
$$

where $g_{i, c, t}$ denotes the value-added growth in industry $i$ of country $c$ in time $t, \alpha_{i, c}$ is a industrycountry fixed effect that captures the growth trend along the time sample in each industry and country pair, $\lambda_{i, t}$ is a sector-time fixed effect that captures global sector-specific shocks in each period and $\mu_{c, t}$ is a country-time fixed effect that captures country-specific macroeconomic shocks, and, therefore, includes the average effect of sovereign default on manufacturing growth.

The variable of interest is the interaction term between a sovereign default indicator $D_{c, t}$ and a sectoral measure of financial dependence $F D_{i}$. Given that $F D_{i}$ takes higher values when an industry shows greater financial dependence, a negative value for $\beta_{F}$ suggests that financial dependent industries experience sharper contractions in the event of default. Spurious estimates for $\beta_{F}$ are controlled for by including a vector $X_{i}$ of alternative industry characteristics, namely, capital intensity, skill intensity and export orientation.

Throughout, coefficients $\beta_{F}$ and $\beta_{X}$ are estimated using a fixed-effect estimator, after eliminating industry-time and country-time effects by subtracting industry-time and country-time averages 
to all variables prior to estimation.

\section{$5.1 \quad$ Data}

Data on value added at the industry level are obtained from the UNIDO INDSTAT3 2005 database. The original database includes 28 sectors at the 3 -digit ISIC classification over a long time period for a large number of developed and developing countries. Data (in current US dollars) are first converted in constant prices using the US GDP deflator, sourced from the World Bank's World Development Indicators 2006, and then log differenced to obtain the growth rate. The large amount of noise, due to misreporting and sporadic observations, is filtered using common procedures for these data. ${ }^{16}$ First, I drop those observations for which the growth rate of value added fall in the top and bottom two point five percent of the distribution. Second, I remove time spells with less than five consecutive observations for each industry-country pair. Third, I exclude all country-year pairs reporting data for less than 10 sectors.

Financial dependence, $F D_{i}$, is measured as the median share of investment not financed with internal cash flow in industry $i$. Data on this index are sourced from Kroszner et al. (2007) who report the original Rajan and Zingales (1998) index at the 3-digit ISIC level and are based on US public companies balance sheet information. As argued by Rajan and Zingales, the focus on US data permits isolation of technological differences across sectors that are invariant across countries.

Capital intensity, $K_{i}$, and skill intensity, $H_{i}$, are measured, respectively, as the ratio of real capital stock on value added in industry $i$ and the ratio of nonproduction worker wages to total wages in industry $i$, averaged over the time sample. These data are taken from the NBER manufacturing productivity database and converted to match the ISIC classification scheme by means of a concordance table.

Export orientation, $\operatorname{Exp}_{i}$, is measured as the average ratio of exports on output in industry $i$ over the time sample. The source is Nicita and Olarreaga (2001). To ease interpretation, all industry indices are normalized such that they have mean zero and standard deviation one.

Default episodes, $D_{c, t}$, are indicated by a dummy variable that takes value one in the first year after the government's announcement. ${ }^{17}$ As in most of the empirical sovereign debt literature, the source of data used to define default episodes is the Standard and Poor's database. A list of default episodes included in the sample is provided in the appendix.

To guarantee parameter stability within the sample, I focus only on developing countries, using the World Bank classification of low, lower middle and upper middle income countries. The final

\footnotetext{
${ }^{16}$ See Borensztein and Panizza (2006).

${ }^{17}$ Since the exact time of default is difficult to identify, I extend the definition of default to the first two year after the government's announcement and to the first three years. In both cases, the estimate of coefficient $\beta_{F}$ remains negative and statistically significant, albeit it moves towards zero as the default window expands.
} 
dataset includes 28 manufacturing sectors in a cross-section of 59 developing countries over the period 1980 to 2000 .

\subsection{Results}

Table 1 reports fixed-effect estimates relative to the 1980 to 1990 and the 1990 to 2000 samples (columns 1-4). The interaction between the default dummy and the financial dependence index enters with a negative sign in all specifications but is statistically significant only in the sub-period 1990 to 2000. Arguably, this result does not reject the theoretical model. Indeed, a key assumption of the model, namely the non-discrimination between foreign and domestic bondholders, suits more realistically the institutional set-up of sovereign debt markets in the 1990s. Indeed, it is only during the 1990s, as a consequence of the Brady plan, that the share of debt issued in anonymous bond markets began to soar in emerging countries while before most sovereign borrowing was granted in the form of syndicated bank loans.

With respect to the $1990 \mathrm{~s}$, the point estimate of coefficient $\beta_{4}$ is also economically significant. In fact, industries that are one standard deviation more financial dependent than the median industry experience a four percentage point decline in their relative growth rate. The last column of table 1 also shows that this effect is robust to the inclusion of additional industry characteristics.

Table 1: Fixed-Effect Estimation

\begin{tabular}{lccccc}
\hline \hline & $(1)$ & $(2)$ & $(3)$ & $(4)$ & $(5)$ \\
& $80-90$ & $80-90$ & $90-00$ & $90-00$ & $90-00$ \\
\hline$D_{c, t} \cdot F D_{i}$ & -0.002 & -0.001 & $-0.042^{* *}$ & $-0.043^{* *}$ & $-0.043^{* *}$ \\
& $(0.011)$ & $(0.011)$ & $(0.018)$ & $(0.021)$ & $(0.021)$ \\
$D_{c, t} \cdot K_{i}$ & & $0.022^{*}$ & & -0.003 & \\
& & $(0.011)$ & & $(0.019)$ & \\
$D_{c, t} \cdot H_{i}$ & & -0.002 & & -0.009 & \\
& & $(0.010)$ & & $(0.016)$ & \\
$D_{c, t} \cdot E x p_{i, c}$ & & 0.105 & & -0.459 & \\
& & $(0.391)$ & & $(0.730)$ & \\
$S S_{c, t} \cdot F D_{i}$ & & & & & $-0.023 * *$ \\
& & & & & $(0.010)$ \\
Obs. & 9332 & 7913 & 7988 & 7239 & 7701 \\
Industries & 28 & 28 & 28 & 28 & 28 \\
Countries & 53 & 40 & 51 & 42 & 49 \\
\hline \hline
\end{tabular}

***,**,* represent significance at $1 \%, 5 \%$, and $10 \%$, respectively. Heteroskedasticity-consistent standard errors are reported within parenthesis. Sector-time and country-time fixed effects were removed prior to estimation by mean differencing. 
During the 1990s, however, the importance of foreign credit to the private sector also increased. One might argue that the trigger of the liquidity crisis lies in the drop of foreign loans to the domestic private sector rather than in the default on domestically held bonds. In fact, Arteta and Hale (2008) provide evidence of a significant decline in foreign credit to the private sector during default episodes. To control for this alternative explanation, I include in the baseline regression an interaction term between the financial dependence index and a dummy capturing sudden stop episodes. Sudden stop episodes, $S S_{c, t}$, are defined as a five percent decline in net financial inflows relative to GDP, as in Levchenko and Mauro (2006), and mainly reflect reversion in bank loans and trade credit. Nonetheless, column 5 in table 1 shows that a sovereign default episode still exerts a significantly stronger effect on financial dependent industries, which exceeds the average (relative) contraction experienced by the same industries during a sudden stop episode. Hence, this evidence shows that the domestic liquidity crisis is not fully explained by the contraction in foreign credit to the private sector.

\section{Conclusion}

Sovereign debt crises in emerging markets are usually associated with financial turmoil and liquidity crises throughout the economy. This connection is suggested by both anecdotal and empirical evidence. In particular, default episodes appear to lead banking crises. However, there is no clear evidence supporting the application of foreign penalties when default occurs.

This paper, then, proposes a novel mechanism linking sovereign defaults with liquidity and banking crises without any intervention of foreign creditors. The model considers a standard unwillingness-to-pay problem assuming that: (i) the enforcement of private contracts is limited and, as a result, public debt represents a source of liquidity; (ii) the government cannot discriminate between domestic and foreign agents. The main result from the model is that external debt might emerge even in the absence of classic default penalties. Indeed, the prospect of triggering a liquidity crisis throughout the economy restores the ex-post incentive for the government to repay. Nonetheless, liquidity crises might arise when economic conditions deteriorate and the government chooses to default to avoid the repayment of foreign agents. Empirical evidence consistent with the connection between sovereign defaults and liquidity crises is also provided.

This paper finally discusses a novel implication of financial reforms in the economy. The common presumption that a complete market for private claims necessarily raises welfare might not be robust to the inclusion of an interaction between private and public debt markets. In particular, the efficiency gains in the allocation of capital across private agents might overestimate the real effect of the reform, which can involve a reallocation of capital from the public to the private sector, which is particularly detrimental in poor countries with large returns on public infrastructures. In particular, the model provides implications on the composition of capital flows whose analysis constitutes a fruitful area of future research. 


\section{References}

Aghion, P., Bacchetta, P., and Banerjee, A. (2004). Financial development and the instability of open economies. Journal of Monetary Economics, 51(6):1077-1106.

Aguiar, M. and Gopinath, G. (2006). Defaultable debt, interest rates and the current account. Journal of International Economics, 69(1):64-83.

Amador, M. (2004). A political model sovereign debt repayment. 2004 Meeting Papers 762, Society for Economic Dynamics.

Arellano, C. (2008). Default Risk and Income Fluctuations in Emerging Economies. American Economic Review, 98(3):690-712.

Arteta, C. and Hale, G. (2008). Sovereign debt crises and credit to the private sector. Journal of International Economics, 74(1):53-69.

Basu, S. (2008). Sovereign debt and domestic economic fragility. MIT. Mimeo.

Bernanke, B. and Gertler, M. (1989). Agency costs, net worth, and business fluctuations. The American Economic Review, 79(1):14-31.

BIS (2000). International banking and financial market developments. BIS Quarterly Review, Bank for International Settlements.

Borensztein, E. and Panizza, U. (2006). Do sovereign defaults hurt exporters? RES Working Papers 1018, Inter-American Development Bank, Research Department.

Borensztein, E. and Panizza, U. (2008). The Cost of Default. IMF Working Papers 08/238, International Monetary Fund.

Broner, F. and Ventura, J. (2008). Rethinking the effects of financial liberalization. Universitat Pompeu Fabra. Mimeo.

Broner, F. and Ventura, J. (2011). Globalization and Risk Sharing. The Review of Economic Studies, 78(1):49-82.

Bulow, J. and Rogoff, K. (1989). Sovereign debt: Is to forgive to forget? American Economic Review, 79(1):43-50.

Caballero, R., Farhi, E., and Gourinchas, P. (2008). An Equilibrium Model of "Global Imbalances" and Low Interest Rates. The American Economic Review, 98(1):358-393.

Caballero, R. and Krishnamurthy, A. (2001). International and domestic collateral constraints in a model of emerging market crises. Journal of Monetary Economics, 48(3):513-548.

Cole, H. L. and Kehoe, P. J. (1998). Models of sovereign debt: Partial versus general reputations. International Economic Review, 39(1):55-70. 
Eaton, J. and Fernandez, R. (1995). Chapter 39 sovereign debt. volume 3 of Handbook of International Economics, pages 2031 - 2077. Elsevier.

Eaton, J. and Gersovitz, M. (1981). Debt with potential repudiation: Theoretical and empirical analysis. The Review of Economic Studies, 48(2):289-309.

Fernandez, R. and Rosenthal, R. W. (1990). Strategic models of sovereign-debt renegotiations. Review of Economic Studies, 57(3):331-49.

Fleming, M. J. (2001). Financial market implications of the federal debt paydown. Staff Reports 120, Federal Reserve Bank of New York.

Gennaioli, N., Martin, A., and Rossi, S. (2009). Institutions, public debt and foreign finance. Economics Working Papers 1170, Department of Economics and Business, Universitat Pompeu Fabra.

Grossman, H. I. and Van Huyck, J. B. (1988). Sovereign debt as a contingent claim: Excusable default, repudiation, and reputation. American Economic Review, 78(5):1088-97.

Guembel, A. and Sussman, O. (2009). Sovereign debt without default penalties. Review of Economic Studies, 76(4):1297-1320.

Holmstrom, B. and Tirole, J. (1998). Private and public supply of liquidity. Journal of Political Economy, 106(1):1-40.

Hubbard, R. (1998). Capital-Market Imperfections and Investment. Journal of Economic Literature, 36(1):193-225.

IMF (2004). Emerging local securities and derivatives markets. World Economic and Financial Surveys, International Monetary Fund.

Kaminsky, G. and Reinhart, C. (1999). The Twin Crises: The Causes of Banking and Balance of Payments Crises. American Economic Review, 89(3):473-500.

Kiyotaki, N. and Moore, J. (1997). Credit cycles. The Journal of Political Economy, 105(2):211248.

Kletzer, K. M. and Wright, B. D. (2000). Sovereign debt as intertemporal barter. American Economic Review, 90(3):621-639.

Kroszner, R., Laeven, L., and Klingebiel, D. (2007). Banking crises, financial dependence, and growth. Journal of Financial Economics, 84(1):187-228.

Kumhof, M. and Tanner, E. (2005). Government debt: A key role in financial intermediation. IMF Working Papers 05/57, International Monetary Fund.

Levchenko, A. A. and Mauro, P. (2006). Do some forms of financial flows help protect from sudden stops? IMF Working Papers 06/202, International Monetary Fund. 
Matsuyama, K. (2004). Financial market globalization, symmetry-breaking, and endogenous inequality of nations. Econometrica, 72(3):853-884.

Mendoza, E. (2006). Endogenous Sudden Stops in a Business Cycle Model With Collateral Constraints: A Fisherian Deflation of Tobin's Q. NBER Working Paper.

Mishkin, F. S. (2006). The Next Great Globalization. Princeton, N.J.: Princeton University Press.

Modigliani, F. and Miller, M. H. (1958). The cost of capital, corporation finance and the theory of investment. The American Economic Review, 48(3):261-297.

Nicita, A. and Olarreaga, M. (2001). Trade and production, 1976-99. Policy Research Working Paper Series 2701, The World Bank.

Panizza, U., Sturzenegger, F., and Zettelmeyer, J. (2009). The economics and law of sovereign debt and default. Journal of Economic Literature, 47(3):651-98.

Rajan, R. G. and Zingales, L. (1998). Financial dependence and growth. American Economic Review, 88(3):559-86.

Reinhart, C. M., Rogoff, K. S., and Savastano, M. A. (2003). Debt intolerance. Brookings Papers on Economic Activity, 34(2003-1):1-74.

Reinhart, V. and Sack, B. (2000). The economic consequences of disappearing government debt. Brookings Papers on Economic Activity, 31(2000-2):163-220.

Sandleris, G. (2008). Sovereign defaults: Information, investment and credit. Journal of International Economics, 76(2):267-275.

Stein, J. C. (2003). Agency, information and corporate investment. In Constantinides, G., Harris, M., and Stulz, R. M., editors, Handbook of the Economics of Finance. Elsevier.

Sturzenegger, F. and Zettelmeyer, J. (2006). Debt defaults and lessons from a decade of crises. Cambridge: MIT Press.

Wright, M. (2002). Reputation and sovereign debt. Mimeo. Stanford.

Yue, V. Z. (2005). Sovereign default and debt renegotiation. 2005 Meeting Papers 138, Society for Economic Dynamics. 
Table 2: Default episodes in the sample

\begin{tabular}{lclc}
\hline \hline Country & Default year & Country & Default year \\
\hline ARG & 1989 & PAN & 1983 \\
BOL & 1986 & PAN & 1987 \\
BOL & 1989 & PER & 1983 \\
CHL & 1983 & PHL & 1983 \\
CRI & 1981 & POL & 1981 \\
CRI & 1984 & RUS & 1998 \\
ECU & 1982 & SEN & 1990 \\
ECU & 1999 & SEN & 1992 \\
EGY & 1984 & SLV & 1981 \\
ETH & 1991 & TUR & 1982 \\
GTM & 1986 & TZA & 1984 \\
HRV & 1992 & URY & 1983 \\
JAM & 1987 & URY & 1987 \\
JOR & 1989 & URY & 1990 \\
KEN & 1994 & VEN & 1983 \\
LKA & 1996 & VEN & 1990 \\
MAR & 1986 & VEN & 1995 \\
MDG & 1981 & ZAF & 1985 \\
MDG & 1986 & ZAF & 1989 \\
MEX & 1982 & ZAF & 1993 \\
MKD & 1992 & & \\
\hline \hline
\end{tabular}

